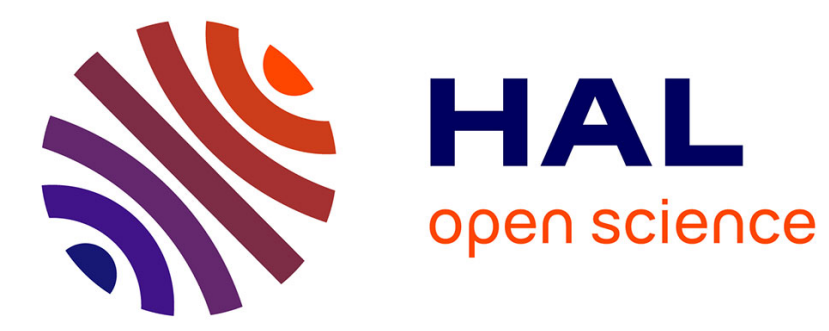

\title{
Selection of rice genotypes for lower methane emission
}

Nirmali Gogoi, K.K. Baruah, Prabhat K. Gupta

\section{To cite this version:}

Nirmali Gogoi, K.K. Baruah, Prabhat K. Gupta. Selection of rice genotypes for lower methane emission. Agronomy for Sustainable Development, 2008, 28 (2), pp.181-186. hal-00886435

\section{HAL Id: hal-00886435 https://hal.science/hal-00886435}

Submitted on 1 Jan 2008

HAL is a multi-disciplinary open access archive for the deposit and dissemination of scientific research documents, whether they are published or not. The documents may come from teaching and research institutions in France or abroad, or from public or private research centers.
L'archive ouverte pluridisciplinaire HAL, est destinée au dépôt et à la diffusion de documents scientifiques de niveau recherche, publiés ou non, émanant des établissements d'enseignement et de recherche français ou étrangers, des laboratoires publics ou privés. 


\title{
Original article
}

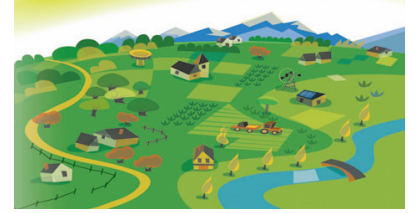

\section{Selection of rice genotypes for lower methane emission}

\author{
Nirmali GoGOI ${ }^{1}$, K.K. BARUAH ${ }^{1,2 *}$, Prabhat K. GUPTA ${ }^{3}$ \\ ${ }^{1}$ Department of Crop Physiology, Assam Agricultural University, Jorhat-785013 Assam, India \\ ${ }^{2}$ Department of Environmental Science, Tezpur University, Napaam District-Sunitpur-784028, Assam, India \\ ${ }^{3}$ National Physical Laboratory, New Delhi-110012, India
}

(Accepted 7 January 2008)

\begin{abstract}
Methane emission from paddy fields can vary with rice cultivars, growth stages of the rice plants (Oryza sativa L.) and environmental conditions. Efforts are being made to study methane emission from rice paddies in different ways. In particular, selection of rice cultivars that emit less methane is practical because it does not change farmer practices. Assam state is a rice-growing state of the northeastern part of India. Assam state is very rich in the rice genepool. Here, we screened rice cultivars popularly grown during the monsoon season of Assam. Five traditional cultivars and five high-yield modern cultivars were grown in the field. Methane emission was measured for the whole crop-growing season. Crop growth parameters including plant height, tiller number, leaf number, plant biomass, leaf area index and grain yield were recorded. Soil parameters such as soil temperature, soil $\mathrm{pH}$ and soil organic carbon were also recorded. Our results show that the methane emission of rice cultivars ranged from $8.83 \mathrm{~g} \mathrm{~m}^{-2}$ to $18.63 \mathrm{~g} \mathrm{~m}^{-2}$ over three and a half months. Variety IR 36 was found to emit the least methane amongst all the cultivars. Five cultivars were identified as high methane-emitting cultivars $\left(>15 \mathrm{~g} \mathrm{~m}^{-2}\right)$. Methane flux values of the crop-growing season exhibited a positive correlation with leaf number, tiller number and leaf area index. Traditional rice cultivars with profuse vegetative growth recorded higher methane flux values compared with high-yielding varieties. This study clearly suggests the possibility of reducing methane emission from the wetland rice ecosystem through appropriate selection of rice cultivars to achieve an economically feasible and technically sound mitigation option of methane emission from farmers' fields.
\end{abstract}

methane / cultivar / biomass / Leaf area index / growth parameters / rice

\section{INTRODUCTION}

The global atmospheric concentration of methane increased from a pre-industrial value of about $715 \mathrm{ppbv}$ to $1732 \mathrm{ppbv}$ in the early 1990s (Crutzen, 1991) and was 1774 ppbv in 2005 (IPCC, 2007). Temperature, organic matter content, fertilizer application, rice plant, $\mathrm{pH}$, redox potential, soil type and water management are the major factors affecting methane emission (Sass et al., 1991; Adhya et al., 1994; Banker et al., 1995; Kongchum et al., 2006; Baruah et al., 1997). Methane emission is reported to be high at the active tillering, flowering and ripening stages of the crop under continuously flooded conditions (Yang and Chang, 1998).

Rice plants regulate the methane budget by providing sources of methanogenic substrates through root-derived carbon including exudates ( $\mathrm{Lu}$ et al., 2000; Aulakh et al., 2001; Ghosh et al., 1995) and by transporting $\mathrm{CH}_{4}$ through aerenchyma (Butterbach-Bahl et al., 1997; Wassmann and

* Corresponding author:

kkbaruah2001@yahoo.com/kkbaruah@tezu.ernet.in
Aulakh, 2000). Enormous genotypic and phenotypic variations amongst rice genotypes have to be considered while assessing the role of rice plants in regulating the global methane budget. Field studies from China (Kesheng and Zhen, 1997), India (Adhya et al., 1994; Shalini et al., 1997; Mitra et al., 1999; Baruah et al., 2002; Gogoi et al., 2005), Italy (Butterbach-Bahl et al., 1997), Japan (Watanabe et al., 1995) and the USA (Sigren et al., 1997) have confirmed the wide variation among rice cultivars in their ability to emit methane.

These findings indicate an ample possibility of selecting rice varieties for lower emission of methane as a biological mitigation option. The traits of high-yielding rice varieties are likely to affect the $\mathrm{CH}_{4}$ source and strength from rice cultivation. A better understanding of factors that control plant-mediated $\mathrm{CH}_{4}$ emissions is required for selection of high-yielding rice varieties with a limited methane emission potential. The objective of the present study was to determine the variation in methane emission rates from different rice cultivars, both traditional and high-yielding, popularly grown in northeast India under a lowland rainfed rice ecosystem. The objective also covers the relationship of methane emission 
Table I. Major characteristics of rice cultivars under study.

\begin{tabular}{lcccc}
\hline Rice Cultivar & $\begin{array}{c}\text { Yield } \\
(\mathrm{t} / \mathrm{ha})\end{array}$ & $\begin{array}{c}\text { Growth duration } \\
\text { (days) }\end{array}$ & $\begin{array}{c}\text { Maximum height } \\
(\mathrm{cm})\end{array}$ & $\begin{array}{c}\text { Tiller No. /hill } \\
\text { (av.) }\end{array}$ \\
\hline Chillong Sali & $3-3.5$ & $150-165$ & 168 & $11-12$ \\
Bogi Sali & $3.5-4$ & $155-170$ & 172 & $11-12$ \\
Peoli & $3.5-4$ & $150-155$ & 154.5 & 12 \\
Betguti Sali & $3-3.5$ & $155-165$ & 143 & 11.20 \\
Kushal & $3.5-5$ & $155-160$ & 135 & 11.80 \\
Aki Sali & $3.2-3.5$ & $150-160$ & 176 & 11.40 \\
IR-36 & $3-5$ & $110-125$ & 93.50 & 11.20 \\
Bahadur & $4-6$ & $150-155$ & 114 & $12.40^{\circ}$ \\
Aghoni & $3.5-5$ & $150-155$ & 181.5 & 12.40 \\
Monohar Sali & $3.5-6$ & $155-160$ & 130 & 12.50 \\
\hline
\end{tabular}

potential with the morphological characteristics of rice plants as preselection criteria for future breeding efforts and to identify cultivars with low methane emission potential.

\section{MATERIALS AND METHODS}

\subsection{Site description and sampling}

The experiment was undertaken during the monsoon Sali (June-Nov) rice growing season at Jorhat under the Upper Brahmaputra Valley Zone (UBVZ) of Assam situated in northeast India. This zone of Assam lies between 25.78 degrees to $28^{\circ} \mathrm{N}$ latitude and $93^{\circ} 50^{\prime} \mathrm{E}$ to $96^{\circ} \mathrm{E}$ longitude. The soils are mostly sandy loam in texture. A large area is also covered by nearly neutral soils and is rich in organic matter (1.23\%). The recorded available $\mathrm{N}, \mathrm{P}$ and $\mathrm{K}$ values are $172.48,17.20$ and $161.28 \mathrm{~kg} / \mathrm{ha}$, respectively. Total Fe, $\mathrm{Zn}, \mathrm{Cu}$ and $\mathrm{Mn}$ contents are $8240,384,80$ and 434 ppm, respectively. The general climatic characteristics of this zone are hot and wet in summer followed by a dry and cool climate in the winter. Average rainfall during monsoon season (June-September) ranges from $1070 \mathrm{~mm}$ to $2050 \mathrm{~mm} /$ annum. Ten rice cultivars, i.e. Chilong sali, Bogi sali, Peoli, Betguti sali, Aki sali, Kushal, IR-36, Bhadur, Aghoni and Monohar sali were transplanted in a well-prepared paddy field. The general descriptions of cultivars are given in Table I. The land area of $1500 \mathrm{~m}^{2}$ was divided into 50 equal-sized subplots $(6 \mathrm{~m} \times 5 \mathrm{~m})$. Each variety was replicated five times in a randomized block design. Thirtyday-old rice seedlings were transplanted in the field at a spacing of $20 \mathrm{~cm} \times 15 \mathrm{~cm}$. Fertilizers were applied at 40:20:20 kg $\mathrm{N}-\mathrm{P}_{2} \mathrm{O}_{5}-\mathrm{K}_{2} \mathrm{O}$ ha ${ }^{-1}$. Half of the urea, and a full dose of $\mathrm{P}_{2} \mathrm{O}_{5}$ and $\mathrm{K}_{2} \mathrm{O}$, were applied at the time of transplanting. The second and third doses of urea were applied at the tillering and panicle initiation stages, as usually done by most of the farmers of this region. Meteorological data of the season was recorded at weekly intervals. Average rainfall of $0.5-15 \mathrm{~mm}$ and minimum and maximum temperatures of 6 and $32{ }^{\circ} \mathrm{C}$ were obtained during the crop-growth period.

\subsection{Methane emission measurement}

The methane emission rate was measured by the static box technique (Buendia et al., 1997). At the measurement sites alu-

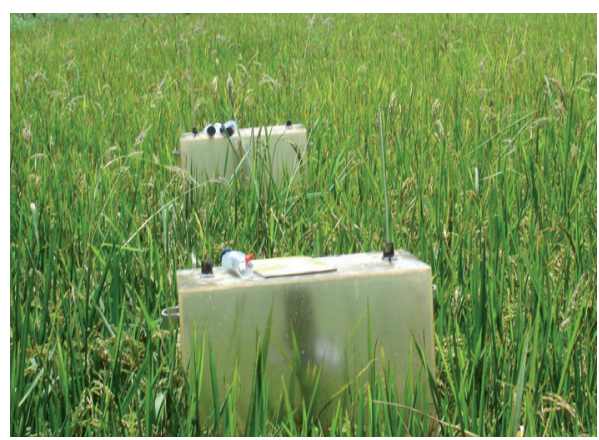

Figure 1. Methane sampling device in the rice experimental field.

minium channels were fixed permanently well in advance of sampling. The bases were mounted with a U-shaped channel to hold water. The perspex box $(30 \mathrm{~cm} \times 50 \mathrm{~cm} \times 70 \mathrm{~cm})$ was than placed over the aluminium channel bases (Fig. 1). The open end of the perspex box rests on the channel. The water seal surrounding the perspex box makes the system airtight. Battery-operated fans inside the perspex box mix the air in the chamber. The box was fitted with tygon tubing terminating in a gastight stopcock and air samples were collected in glass bottles by the water displacement method. Glass air-sampling bottles were fitted with a three-way stopcock and a neck with a self-sealing silicon rubber septum. Samples were collected at fixed intervals of $0,15,30$ and 45 minutes. The averages of all fluxes were considered as the flux value for the day. Methane fluxes were determined once a week in the morning and afternoon, starting 15 days after transplanting and continuing over the entire crop-growing season. After collection, samples were brought to the laboratory and concentration was determined by a gas chromatograph (Varian 3800), fitted with a flame ionization detector (FID) and Porapak N column, $180 \mathrm{~cm}$ long and $1 / 8$ inch outside diameter. Column, detector and injector temperatures were maintained at $90{ }^{\circ} \mathrm{C}, 130{ }^{\circ} \mathrm{C}$ and $130{ }^{\circ} \mathrm{C}$, respectively. Nitrogen was used as the carrier gas, hydrogen as the fuel gas and zero air as the supporting gas with flow rates of 20,30 and $250 \mathrm{~mL} \mathrm{~min}^{-1}$, respectively. Ambient and box air temperatures, barometric pressure and water level inside the chamber were measured during each sample collection to calculate the chamber air volume at standard temperature and pressure. Field water level, soil temperature, soil organic carbon content (Jackson, 1973) and soil pH were determined using a Systronics Griph model D pH meter 327 during each methane sampling period.

Plant growth parameters such as plant height, tiller number, leaf number, root biomass and shoot biomass were determined at weekly intervals. Leaf area was measured by using a portable laser leaf area meter (model CI-203, USA). Methane flux $(\mathrm{F})$ was calculated from the temporal increase in methane concentration inside the perspex box using the equation of Parashar et al. (1997).

Cumulative methane emission for the entire growth period $\left(\mathrm{E}_{\text {sif }}\right)$ was computed by plotting the methane efflux values against the days of sampling and the area covered under the plot of such relationship was expressed as $\mathrm{g} \mathrm{m}^{-2}$. The results 


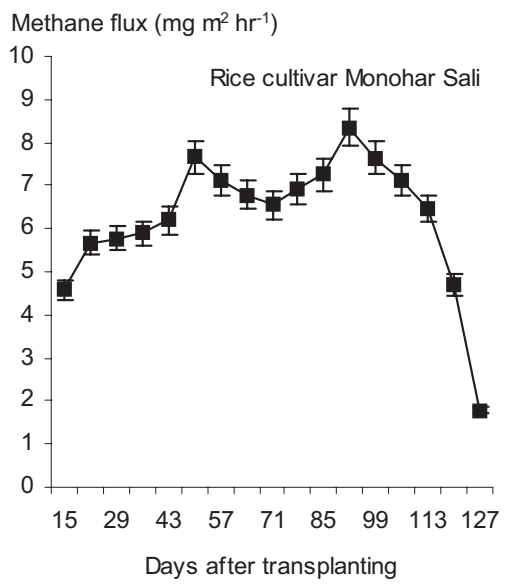

Figure 2. Methane flux from traditional rice cultivar Monohar Sali with two distinct emission peaks. Total $\mathrm{CH}_{4}$ emission by this cultivar during the growing season $\mathrm{E}_{\text {sif }}=18.63 \mathrm{~g} \mathrm{~m}^{-2}$, the highest among all the cultivars. Bar indicates \pm SE.

of methane efflux values were processed and plotted against days after transplanting.

\subsection{Statistical analysis}

As the same sites were sampled over consecutive days, a two-way 'repeated measurements' analysis of variance (ANOVA) was used to determine the differences in gas fluxes considering cultivars as sources of variation in gas flux. Simple linear regressions were performed to find the relationship between the various parameters with methane emission using the software SPSS for MS Windows Version 10.0. Significant differences were at the $P<0.05$ and $P<0.01$ levels.

\section{RESULTS AND DISCUSSION}

Two methane emission peaks were clearly observed at two different growth stages of the plants (Figs. 2-5). In all the cultivars the first maximum was recorded at 43 to 57 days after transplanting, corresponding to methane flux values between 5.5 and $7.2 \mathrm{mg} \mathrm{m}^{-2} \mathrm{~h}^{-1}$. The largest variation in methane emission during the early growth period arose from decomposition of available organic matter in the soil (Xu et al., 2000). The recorded date of emission peaks varied with the cultivars and this may be the result of variable amounts of exudate utilized in methane formation in the rhizosphere of different cultivars. Exudate quality and quantity influence the rate of methane generation, as the root exudate contributes the substrate for methane formation in rice fields (Kimura et al., 2004). The second maximum of methane flux in all the cultivars ranged between 5.5 and $8.3 \mathrm{mg} \mathrm{m}^{-2} \mathrm{~h}^{-1}$ and was recorded between 71 and 99 days after transplanting, corresponding to the panicle initiation stage of the crop. The total methane emission from soil planted with different cultivars ranged between $8.83 \mathrm{~g} \mathrm{~m}^{-2}$ and $18.63 \mathrm{~g} \mathrm{~m}^{-2}$ and the maximum was recorded in the cultivar Monohor sali followed by Bogi sali, Aki sali, Chilong

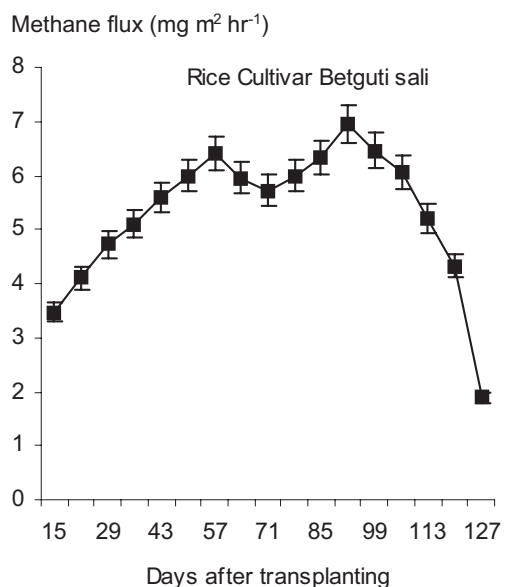

Figure 3. Methane flux from traditional rice cultivar Betguti Sali with two distinct emission peaks. Total $\mathrm{CH}_{4}$ emission by this cultivar during the growing season $\mathrm{E}_{\mathrm{sif}}=15.80 \mathrm{~g} \mathrm{~m}^{-2}$, the lowest among traditional cultivars. Bar indicates $\pm \mathrm{SE}$.

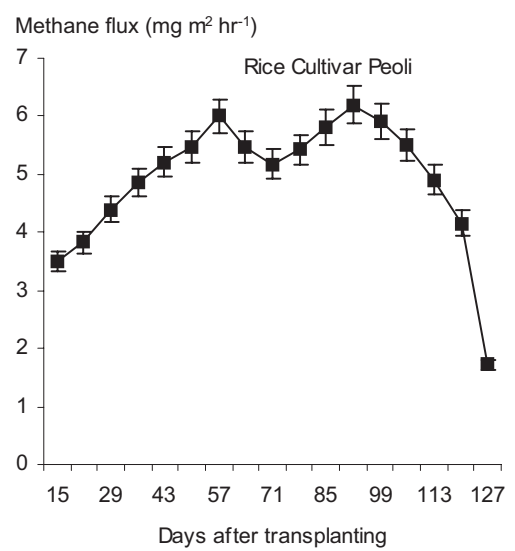

Figure 4. Methane flux from high yielding rice cultivar Peoli with two distinct emission peaks. Total $\mathrm{CH}_{4}$ emission by this cultivar during the growing season $E_{\text {sif }}=14.33 \mathrm{~g} \mathrm{~m}^{-2}$, the highest among the high yielding cultivars. Bar indicates $\pm \mathrm{SE}$.

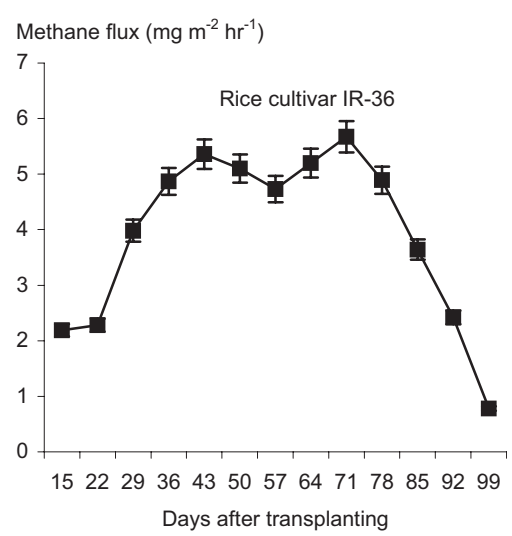

Figure 5. Methane flux from high yielding rice cultivar IR-36 with two distinct emission peaks. Total $\mathrm{CH}_{4}$ emission by this cultivar during the growing season $\mathrm{E}_{\mathrm{sif}}=8.83 \mathrm{~g} \mathrm{~m}^{-2}$, the lowest among all the cultivars. Bar indicates \pm SE. 


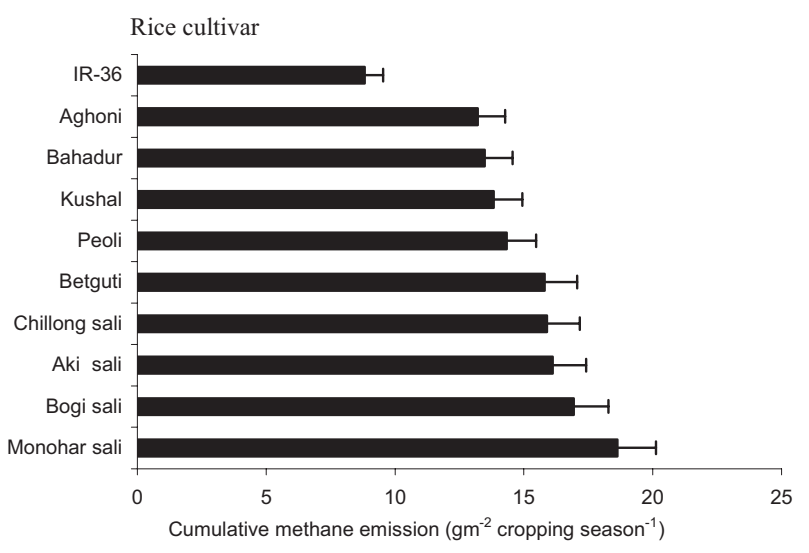

Figure 6. Cumulative methane efflux from ten rice cultivars planted under uniform field condition. Bar indicates $\pm \mathrm{SE}$.

sali, Betguti sali, Peoli, Kushal, Bahadur, Aghoni and IR-36 (Tab. IIa,b). A general increase in emission of methane was recorded along with the increase in plant biomass. A significant positive correlation of these two parameters was recorded during the panicle initiation stage (Tab. III). A dependence of methane emission on biomass has been reported by other authors (Cicerone et al., 1983; Sinha, 1995; Shalini et al., 1997; Holzapfel et al., 1986).

The plant growth parameters of the ten cultivars revealed large differences among them (Tab. IIa, $\mathrm{b}$ ). The root biomasses of the cultivars were small at the seedling stage but increased 5-17 times at panicle initiation and flowering. Similar trends were observed for shoot biomass as well. Among all the traditional cultivars, Monohor sali exhibited the highest aboveground biomass. Plants continued to accumulate both root and shoot biomass along with growth until flowering. However, shoot biomass in general declined at maturity. The increase in root or aboveground biomass during plant growth until flowering determines the corresponding increase in methane emission potential. In the present study, a positive correlation was observed between aboveground biomass and methane emission by rice plants. This is due to the contributions of increased plant biomass in terms of root exudates inducing $\mathrm{CH}_{4}$ production, as reported by Minoda and Kimura (1994), and Aulakh et al. $(2000,2001)$.

Cultivars showed enormous variations in methane emissions both at individual growth stages as well as for the complete season. The traditional tall cultivar Monohor sali showed a higher seasonal integrated methane flux value $\left(E_{\text {sif }}\right)$ than all the other cultivars studied. Betguti sali recorded the lowest $\mathrm{E}_{\text {sif }}$ value compared with the other traditional cultivars. Among the high-yielding cultivars, Peoli, a tall cultivar, recorded the highest seasonal integrated value compared with IR-36, a shortduration high-yielding dwarf rice cultivar.

In all the cultivars, the mean flux value of methane at the panicle initiation stage was higher than that of the active tillering stage of the rice crop. This could be related to increasing availability of substrate for methanogenic bacteria in the form of root exudates and sloughed-off root cap cells, as reported by Chidthaisong et al. (1999); Lu et al. (2000). The higher flux value at the panicle initiation stage was found to be significantly correlated with higher root vigor in terms of biomass (Tab. IV). Differences in soil organic carbon values recorded during the crop-growth period might be related to variation in the root exudation pattern of the cultivars. The decrease in the emission pattern after panicle initiation is due to the reduced permeability of the root epidermal layer due to aging, in addition to the choking of the aerenchyma with intruding water. In the present study, a positive correlation of methane flux with leaf number and leaf area index (LAI) was observed (Tab. IV). Higher leaf number and leaf area provide a higher number of pores per unit leaf area and thus greater ventilation for methane transport, leading to higher flux values (Nouchi, 1994; Baruah et al., 2002; Gogoi et al., 2003), and this might be the reason for the positive correlation between leaf number and methane flux.

Growth duration is another important factor that regulates methane emission, as observed in the present study. Similar findings have been reported for a long-duration variety, Ratna, that emitted more methane than Ananda, a short-duration variety, by Adhya et al. (1994).

\section{CONCLUSION}

Genotypic differences in emission of methane from rice paddies are reported in the present study. Low methaneemitting rice cultivars, e.g. IR-36, Aghoni, etc., were identified. Traditional rice varieties, e.g. Monohar sali, Bogi sali, etc., which otherwise have wide adaptability to different agroecological environments, are popular among the rice farmers of this region. These varieties were found to emit more methane into the atmosphere. It is suggested to discourage the cultivation of these varieties in order to cut down the methane emissions into the atmosphere. Important plant physiological parameters such as leaf number, tiller number and plant biomass, which regulate the emission of methane, are identified. These physiological traits can help rice breeders to develop new low methane emitting genetic lines of rice.

Although there is current knowledge on methane emission from other rice-growing countries, the findings reported are new from this part of India, since this region grows rice throughout the year in different agroecosystems. Hence, the results are considered to be novel from the point of view of greenhouse gas emission reduction.

Indian agriculture in the 21 st century faces a major challenge of enhancing and sustaining the food and nutritional security of a population of over one billion. To this end, the agricultural productivity needs to be doubled by 2050 . The most viable option to raise rice production is to develop new and innovative agricultural technologies. Cultivation of highyielding rice varieties along with hybrid rice could become the anchor of food security in a world faced with the challenges of greenhouse gas emission and related climate change. Therefore, cultivation of high-yielding rice genotypes with less methane emission will be a major contributor to sustainable agriculture in Indian farming systems. 
Table II. (a) Plant growth parameters, soil organic carbon and methane emission from different cultivars at maximum tillering stage.

\begin{tabular}{|c|c|c|c|c|c|c|c|}
\hline $\begin{array}{l}\text { Growth } \\
\text { stage/Variety }\end{array}$ & $\begin{array}{l}\text { Plant height } \\
(\mathrm{cm})\end{array}$ & $\begin{array}{c}\text { No. of } \\
\text { tillers/hill }\end{array}$ & $\begin{array}{l}\text { Leaf } \\
\text { No./hill }\end{array}$ & $\begin{array}{c}\begin{array}{c}\text { Biomass } \\
\text { (shoot) }\end{array}\end{array}$ & $\begin{array}{c}\text { Biomass } \\
\text { (root) }\end{array}$ & $\begin{array}{c}\text { Soil Organic } \\
\text { carbon }(\%)\end{array}$ & $\begin{array}{c}\text { Methane } \\
\left(\mathrm{mg} \mathrm{m}^{-2} \mathrm{hr}^{-1}\right)\end{array}$ \\
\hline Bogi sali & 100.30 & 12.60 & 73.80 & 19.78 & 4.15 & 0.38 & 6.86 \\
\hline Betguti sali & 93.64 & 12.00 & 57.60 & 12.17 & 5.32 & 0.38 & 6.40 \\
\hline Aki sali & 98.22 & 12.40 & 55.60 & 14.28 & 5.03 & 0.37 & 6.92 \\
\hline IR-36 & 59.06 & 12.25 & 42.00 & 8.12 & 3.74 & 0.36 & 5.36 \\
\hline Kushal & 81.94 & 14.00 & 56.60 & 13.25 & 5.84 & 0.35 & 5.82 \\
\hline Peoli & 98.14 & 14.00 & 60.20 & 21.47 & 5.96 & 0.37 & 6.00 \\
\hline
\end{tabular}

(b) Plant growth parameters, soil organic carbon and methane emission from different cultivars at panicle initiation stage.

\begin{tabular}{|c|c|c|c|c|c|c|c|}
\hline $\begin{array}{l}\text { Growth } \\
\text { stage/Variety }\end{array}$ & $\begin{array}{l}\text { Plant height } \\
(\mathrm{cm})\end{array}$ & $\begin{array}{c}\text { No. of } \\
\text { tillers/hill }\end{array}$ & $\begin{array}{c}\text { Leaf } \\
\text { No./hill }\end{array}$ & $\begin{array}{c}\text { Biomass } \\
\text { (shoot) }\end{array}$ & $\begin{array}{c}\text { Biomass } \\
\text { (root) }\end{array}$ & $\begin{array}{c}\text { Soil Organic } \\
\text { carbon }(\%)\end{array}$ & $\begin{array}{c}\text { Methane } \\
\left(\mathrm{mg} \mathrm{m}^{-2} \mathrm{hr}^{-1}\right)\end{array}$ \\
\hline Bogi sali & 158.66 & 13.60 & 68.60 & 60.63 & 9.76 & 0.33 & 7.83 \\
\hline Betguti sali & 124.10 & 13.20 & 50.20 & 54.37 & 9.74 & 0.34 & 6.95 \\
\hline Aki sali & 148.64 & 13.20 & 53.00 & 60.38 & 9.13 & 0.34 & 7.36 \\
\hline IR-36 & 89.08 & 13.40 & 41.80 & 23.44 & 5.43 & 0.32 & 5.67 \\
\hline Kushal & 110.98 & 13.20 & 47.40 & 40.43 & 8.37 & 0.29 & 6.25 \\
\hline Peoli & 138.76 & 14.40 & 54.80 & 41.27 & 10.33 & 0.35 & 6.20 \\
\hline
\end{tabular}

Table III. Correlation Coefficient between methane emission and plant growth parameters.

\begin{tabular}{|c|c|c|c|}
\hline \multicolumn{4}{|c|}{ Methane $\left(\mathrm{mg} \mathrm{m}^{-2} \mathrm{hr}^{-1}\right)$} \\
\hline Growth parameters & Maximum tillering stage & Panicle initiation stage & $\begin{array}{l}\text { Average of maximum tillering stage and } \\
\text { panicle initiation stage }\end{array}$ \\
\hline Plant height $(\mathrm{cm})$ & $0.833^{* *}$ & $0.909^{* *}$ & $0.842^{* *}$ \\
\hline Biomass (shoot) & 0.530 & $0.937^{* *}$ & $0.733^{* *}$ \\
\hline Biomass (root) & 0.273 & $0.708^{*}$ & $0.608^{* *}$ \\
\hline Leaf area index (LAI) & $0.719^{* *}$ & $0.692^{* *}$ & $0.751^{* *}$ \\
\hline
\end{tabular}

** Correlation is significant at the 0.01 level (2-tailed).

* Correlation is significant at the 0.05 level (2-tailed).

Correlation analysis was done by Pearson Correlation coefficient method using a software SPSS for MS Windows Version 10.0.

Table IV. Methane emission $\left(\mathrm{mg} \mathrm{m}^{-2} \mathrm{hr}^{-1}\right)$ from paddy soil to the atmosphere at different rice growth stages over the entire rice-growing season.

\begin{tabular}{|c|c|c|c|c|c|c|c|c|c|c|}
\hline \multirow{2}{*}{$\begin{array}{l}\text { Rice growth } \\
\text { stage }\end{array}$} & \multicolumn{10}{|c|}{ Cultivars } \\
\hline & $\begin{array}{c}\text { Chillong } \\
\text { Sali }\end{array}$ & $\begin{array}{c}\text { Bogi } \\
\text { sali }\end{array}$ & Peoli & $\begin{array}{c}\text { Betguti } \\
\text { Sali }\end{array}$ & Kushal & Aki Sali & IR-36 & Bahadur & Aghoni & $\begin{array}{c}\text { Monohar } \\
\text { Sali }\end{array}$ \\
\hline Early tillering & $5.34 b^{*}$ & $5.36 \mathrm{~b}$ & $4.86 \mathrm{~cd}$ & $5.10 \mathrm{bc}$ & $4.53 \mathrm{~d}$ & $5.27 \mathrm{~b}$ & $3.98 \mathrm{e}$ & $4.59 \mathrm{~d}$ & $4.86 \mathrm{~cd}$ & $5.89 a$ \\
\hline Panicle initiation & $7.12 \mathrm{c}$ & $7.83 b$ & $6.20 \mathrm{e}$ & $6.63 d$ & $6.25 \mathrm{c}$ & $7.36 \mathrm{c}$ & $5.67 \mathrm{c}$ & 6.39de & $5.60 \mathrm{f}$ & $8.35 \mathrm{a}$ \\
\hline Ripening & $5.19 b$ & $6.35 \mathrm{a}$ & $4.83 c$ & $5.20 \mathrm{~b}$ & $4.71 \mathrm{c}$ & $5.14 \mathrm{~b}$ & $3.64 \mathrm{e}$ & $4.72 \mathrm{c}$ & $3.54 \mathrm{~d}$ & $6.46 a$ \\
\hline
\end{tabular}

* Values are the average of four consecutive fluxes. With different letter in the same column, the difference is significant at $P<0.05$ level by Duncan's test. 
Acknowledgements: We acknowledge the Department of Science and Technology (DST), Govt. of India, for sponsoring the project. Sincere thanks to Dr. P. Sanjeeva Rao, Scientist F (DST) and to Dr. A. K. Pathak, Director of Research, Assam Agricultural University, Jorhat, for providing all sorts of facilities for carrying out the investigation.

\section{REFERENCES}

Adhya T.K., Rath A.K., Gupta P.K., Rao V.R., Das S.N., Parida K.M., Parashar D.C., Sethunathan N. (1994) Methane emission from flooded rice fields under irrigated conditions, Biol. Fert. Soils 18, 245-248.

Aulakh M.S., Bodenbender J., Wassmann R., Rennenberg H. (2000) Methane transport capacity of rice plants. II. Variations among different rice cultivars and relationship with morphological characteristics, Nutr. Cycl. Agroecosys. 58, 367-377.

Aulakh M.S., Wassmann R., Bueno C., Rennenberg H. (2001) Characterization of root exudates at different growth stages of rice (Oryza sativa L.) cultivars, Plant Biol. 3, 139-148.

Banker B.C., Kludz H.K., Alford D.P., Delaune R.D., Lindau C.W. (1995) Methane sources and sinks in paddy rice soils:relationship to emissions, Agr. Ecosyst. Environ. 53, 247-251.

Baruah K.K., Parashar D.C., Gupta P.K., Sharma R.C., Jain M.C., Mitra A.P. (1997) Effect of water management and rice genotypes on methane emission from paddy field, Indian J. Radio Space Phys. 26, 77-81.

Baruah K.K., Gogoi N., Gogoi B., Goswami S., Barman B., Gupta P.K. (2002) Plant and soil factors associated with methane emission from irrigated rice eosystem of Assam, in: Ham J. Van., Baede A.P.M., Guicherit R., Williams-Jacobse J.G.F.M. (Eds.), Non- $\mathrm{CO}_{2}$ greenhouse gases scientific understanding, control options and policy aspacts, Millpress-Rotterdam, The Netherlands, pp. 101-116.

Buendia L.V., Neue H.U., Wassmann R., Lantin R.S., Javellana A.M., Yuchang X., Makarim A.K., Corton T.M., Charoensilp N. (1997) Understanding the nature of methane emission from rice ecosystems as basis of mitigation stratigies, Appl. Energ. 56, 433-444.

Butterbach-Bahl K., Papen H., Rennenberg H. (1997) Impact of gas transport through rice cultivars on methane emission from rice paddy fields, Plant Cell Environ. 20, 1175-1183.

Chidthaisong A., Obata H., Watanabe I. (1999) Methane formation and substrate utilization in anaerobic rice soils as affected by fertilization, Soil Biol. Biochem. 31, 135-143.

Cicerone R.J., Shetter J.D., Delwiche C.C. (1983) Seasonal variation in methane flux from California rice paddy, J. Geophys. Res. 88, $11022-11024$.

Crutzen P.J. (1991) Methane's sinks and sources, Nature 350, 380-381.

Ghosh S., Jain M.C., Sinha S. (1995) Estimates of global methane production from rice paddies based on substrate requirement, Curr. Sci. 69, 937-939.

Gogoi N., Baruah K.K., Gogoi B., Gupta P.K. (2003) Physiological parameters of rice associated with emission of methane from different agroecosystem, Indian J. Plant Physiol. (special issue) 597-601.

Gogoi N., Baruah K.K., Gogoi B., Gupta P.K. (2005) Methane emission characteristics and its relations with plant and soil parameters under irrigated rice ecosystem of north east India, Chemosphere 59, $1677-1684$

Holzapfel P.A., Conrad R., Seiler W. (1986) Effects of vegetation on the emission of methane from submerged paddy soil, Plant Soil 92, $223-233$.

IPCC - Intergovernmental Panel on Climate Change (2007) Contribution of Working Group I to the Fourth Assessment Report of the
Intergovernmental Panel on Climate Change Greenhouse gas inventory workbook, in: 10th Session of Working Group I of the IPCC, Paris.

Jackson M.L. (1973) Soil Chemical Analysis, Prentice Hall of India Pvt. Ltd., New Delhi.

Kesheng S., Zhen L. (1997) Effect of rice cultivars and fertilizer management on methane emission in a rice paddy in Beijing, Nutr. Cycl. Agroecosys. 49, 139-146.

Kimura M., Murase J., Lu Y. (2004) Carbon cycling in rice field ecosystems in the context of input, decomposition and translocation of organic materials and the fates of their end products $\left(\mathrm{CO}_{2}\right.$ and $\left.\mathrm{CH}_{4}\right)$, Soil Biol. Biochem. 36, 1399-1416.

Kongchum Manoch, Bollich P.K., Hudnall W.H., Delaune R.D., Lindau C.W. (2006) Decreasing methane emission by better crop management, Agron. Sustain. Dev. 26, 45-54.

Lu Y., Wassmann R., Neue H.U. (2000) Response of methanogenesis in anaerobic rice soils to exogenous substrates, Soil Biol. Biochem. $32,1683-1690$.

Minoda T., Kimura M. (1994) Contribution of photosynthesized carbon to the methane emitted from paddy fields, Geophys. Res. Lett. 21, 2007-2010.

Mitra S., Jain M.C., Kumar S., Bandyopadhya S.K., Kalra N. (1999) Effect of rice cultivars on methane emission, Agr. Ecosyst. Environ. 73, 177-183.

Nouchi I. (1994) Mechanisms of methane transport through rice plants, in: " $\mathrm{CH}_{4}$ and $\mathrm{N}_{2} \mathrm{O}$ : Global Emissions and Controls from Rice Fields and Other Agricultural and Industrial Sources", in: Minami K., Mosier A., Sass R.L. (Eds.), pp. 87-104, NIAES Series 2, Tsukuba, Japan.

Parashar D.C., Mitra A.P., Gupta P.K., Rai J., Sharma R.C., Singh N., Koul S., Ray H.S., Das S.N., Parida K.M., Rao S.B., Kanungo S.P., Ramasami T., Nair B.U., Swamy M., Singh G., Gupta S.K., Singh A.R., Saikia B.K., Barua A.K.S., Pathak M.G., Iyre C.S.P., Gopalakrishnan M., Sane P.V., Singh S.N., Banerjee R., Sethunathan N., Adhya T.K., Rao V.R., Palit P., Saha A.K., Purkait N.N., Chaturvedi G.S., Sen S.P., Sen M., Sarkar B., Banik A., Sinha S.K. (1997) Methane budget from paddy fields in India, Chemosphere 33, 737-757.

Sass R.L., Fisher F.M., Harcombe P.A., Turner F.T. (1991) Mitigation of methane emission from rice fields: effect of incorporated rice straw, Global Biogeochem. Cy. 5, 275-288.

Shalini S., Kumar S., Jain M.C. (1997) Methane emission from two Indian soils planted with different rice cultivars, Biol. Fert. Soils $25,285-289$.

Sigren L.K., Byrd G.T., Fisher F.M., Sass R.L. (1997) Composition of soil acetate concentrations and methane production, transport and emission in two rice cultivars, Global Biogeochem. Cy. 11, 1-4.

Sinha S.K. (1995) Global methane emission from rice paddies: Excellent methodology but poor extrapolation, Curr. Sci. 68, 643-646.

Wassmann R., Aulakh M.S. (2000) The role of rice plants in regulating mechanisms of methane emissions, Biol. Fert. Soils 31, 20-29.

Watanabe A., Kajiwara M., TashiroT., Kimura M. (1995) Influence of rice cultivar on methane emission from paddy fields, Plant Soil 176, $51-56$.

Xu H., Cai Z.C., Jia Z.J., Tsuruta H. (2000) Effect of land management in winter crop season on $\mathrm{CH}_{4}$ emission during the following flooded and rice growing period, Nutr. Cycl. Agroecosys. 58, 12-18.

Yang S.S., Chang H.L. (1998) Effect of environmental conditions on $\mathrm{CH}_{4}$ production and emission from paddy soil, Agr. Ecosyst. Environ. $69,69-80$. 